\author{
(online) $=$ ISSN $2285-3642$ \\ ISSN-L = $2285-3642$ \\ Journal of Economic Development, Environment and People \\ Volume 3, Issue 1, 2014 \\ URL: http://jedep.spiruharet.ro \\ e-mail: office jedep@spiruharet.ro
}

\title{
Harmonization of accounting in the process of globalization of economic activities
}

\author{
Associated Professor Floarea GEORGESCU, $\mathrm{PhD}^{1}$, Professor Cicilia IONESCU, $\mathrm{PhD}^{2}$ \\ Spiru Haret University, str. Fabricii, no. 46 G, sect. 6, Bucharest ${ }^{1}$ \\ georgescuflori@yahoo.com \\ Spiru Haret University, str. Fabricii, no. 46 G, sect. 6, Bucharest ${ }^{2}$ \\ ciciliaionescu@yahoo.com
}

\begin{abstract}
Once with the Romania adhering at the European Union the public accounting system was transformed and adapted according to the requirements imposed by the international public sector accounting standards (IPSAS).This fact had imposed the appearance of legislative norms and provisions adapted to the actual requirements, by taking into account the growing and complex level of economic activities where the irreversible process of globalization takes place.

The changes due to the economic politics, especially the new configuration of the international economic relations, relations characterized by an intense and irreversible process of globalization, have conducted to the implementation of a unitary and uniform legislation, particularly for the member states of EU. The accounting reform has begun through the harmonization of legislation according to the requirements and provisions of International Accounting Standards and European Directives.

The ampleness and the rapid rhythm of informational society's development have implicitly leaded to the development of accounting information's importance and dimension. The decisive role of the accounting information had conducted to the accentuated growth of the interest, manifested at all informational society's level, from the development of activities in financial and economical domain point of view.

The accounting normalization process imposed the development of norms and provisions necessary to the drawing up of accounting documents, by defying methods and a specialized terminology, applied in the activity of entities and accounting specialists.
\end{abstract}

Keywords: financial security, public accounting system, accounting harmonization, international public sector accounting standards (IPSAS).

\section{JEL Codes: M41}

\section{Introduction}

The accounting depreciation is realized through the inuring accounting norms and regulations, improved in order to provide an identical compatibility and interpretation of the events and transactions performed in many states, more precisely to offer exact information for the investors, by reflecting the economic performances in a credible, relevant, veridical and intelligible manner. 


\author{
(online) = ISSN $2285-3642$ \\ ISSN-L = 2285-3642 \\ Journal of Economic Development, Environment and People \\ Volume 3, Issue1, 2014 \\ URL: $\underline{\text { http://jedep.spiruharet.ro }}$ \\ e-mail: office jedep@spiruharet.ro
}

\title{
2. Globalization of economic activities
}

This objective can be realized with the help of authorized institutions and organizations that established very clear the implementation methodology and the stages and periods of time, for all the participating countries to international economic transactions. At global level is imposed the implementation of an unitary standard for accounting documents, offering this way the access to accounting information according to the needs and requirements of the applicant, regardless of the level of complexity and utility of these information.

The transformations which took place because of the economic activities globalization process offer new directions to accounting and fiscality, directions that aim to satisfy the needs of multinational companies for informing, the validation of accounting information among the national accounting system and the creation at international level of a financial indicators system for all the participants. The fulfilment of this objective is influenced by the fiscal interest of the state, an interest promoted through specific juridical regulations and proper economic and fiscal politics. Based on the application way of universal accounting principles and conventions, the analysts draw attention on the economic priority of events and transactions compared with the fiscal priority. Such conceptual frame is founded on fundamental objectives and principles that accounting norms and proceedings are created on, objectives which are approved by the liberal accounting profession.

The complying with this frame can lead to the independence of accounting towards the fiscal norms and regulations, giving to managers the opportunity to establish the way the financial situations are presented, as long as the fundamental principle of accounting, principle of sincerity, is respected. In other words, the data contained in accounting documents can be processed based on norms, principles and proceedings characteristic to the universal accounting law, without interferences from the state. In these conditions, the investors could form an opinion regarding the reality of financial position and performance of the enterprise and their decisions regarding the investments can be successful. The promoting of the substance over form principle leads to a fund mutation concerning the presentation of annual financial situations; this way the accounting is free of imposed juridical norms and regulations, and the relation between accounting and fiscality is neutral with regard to the users of financial information. Therefore, the accounting represents a privileged source of information for fiscal organisms, as the majority of fiscal taxes and duties is established based on information provided by the accounting.

It is difficult to determine a relation between accounting and fiscality, because in reality the two of them are reciprocally influencing each other, as accounting offers a prime material for the calculation of taxes and other fiscal obligations and the fiscality influences accounting through specific regulations that have as objective the collection of financial resources for the state budget, the local budgets and other public organisms, resource necessary to both the state and the administrative territorial institutions.

As the main source of data, the accounting is delimited of fiscality and tries to be neutral, but also comparable as a communication system for all users of accounting information. Analyzed from the relation 


\author{
(online) $=$ ISSN $2285-3642$ \\ ISSN-L = 2285-3642 \\ Journal of Economic Development, Environment and People \\ Volume 3, Issue 1, 2014 \\ URL: $\underline{\text { http://jedep.spiruharet.ro }}$ \\ e-mail: office jedep@spiruharet.ro
}

between fiscality and fiscal administration point of view, the accounting is transparent to fiscal administration in comparison with fiscality. A generating source of information, accounting is delimited from both fiscal administration and fiscality. In order to be neutral, and also compatible as a communication system with it users, the accounting must be based upon clear, relevant, principles and norms, to use a proper, standardized and uniform terminology.

Through accounting, the allocation of revenues and expenses during the financial exercise must be underlined. The fix assets evaluation is made through the acquisition cost, the production price, the utility value, the just value or other similar values. In public institution, the evaluation of fix assets is made with the help of inventory, realised in every year. The pluses or minuses and the value depreciation is underlined in the accounting evidence.

The fundamental problem of the report between accounting and fiscality is composed of the principles, norms, regulations found in the accounting and fiscal law, principles that are not compatible in all cases, because the accounting information is formalized through laws and the fiscal information is based upon clear norms and principles defined by the fiscal law, this fact establishing the dependence of accounting on fiscality.

When the manager analyses the risks, he works with a team of analysts and applies a series of techniques and methodologies in order to identify solutions to any practical problems. As a general rule, the analysis of the report between accounting and fiscality of an enterprise imposes taking into account the fiscal risk resulting from the application of fiscal regulations. The public institutions credibility and the level of trust that citizens have in these institutions are factors which help to the good functioning of the society.

The International Public Sector Accounting Standard (IPSAS) is based on the content of the International Accounting Standard no.1 The presentation of financial situations, standard published by the International Accounting Standards Committee (IASC).

The International Accounting Standards Board (ISAB) and the International Accounting Standard Committee Foundation (IASCF) were established in 2001 in order to replace IASC.

The International Accounting Standards elaborated by IASC are applied until they are with draw by IASB.

Texts extracted from IAS 1 are reproduced in the publication of Committee for Public Sector of International Accountant Federation with the permission of IASB.

The Council of International Accountants Federation for International Public Sector Accounting Standards (IPSASB) elaborates accounting standards for public institutions, known under the name of International Public Sector Accounting Standards (the IPSAS).

IPSASB recognizes the significant benefits of obtaining financial information comparable in all jurisdictions and considers that all IPSAS will play a key role in fulfilling these benefits. IPSASB encourages the governments and the national specialists to implicate in the elaboration of personalized standard harmonized with IPSAS.

IPSASB issues IPSAS concerning the financial reporting based on cash accounting and commitment accounting. The IPSAS for the commitment accounting are based on the International Financial Reporting 


\author{
(online) $=$ ISSN $2285-3642$ \\ ISSN-L = $2285-3642$ \\ Journal of Economic Development, Environment and People \\ Volume 3, Issue1, 2014 \\ URL: $\underline{\text { http://jedep.spiruharet.ro }}$ \\ e-mail: office jedep@spiruharet.ro
}

Standards (IFRS), issued by the Council for the International Accounting Standards, where the requirements of these standards are applicable to the activities specific to public sector. Also, it refers to financial reporting problems specific to public sector, which are not covered by IFRS. ${ }^{1}$

Thus, the commitment accounting adopted by the public sector represents an important objective of the public finances reform, because in an international and European context, it brings more benefits to the users of financial information, as:

$>$ The commitment accounting is more complex than the cash accounting

$>$ The public institutions are obliged to keep track of assets, debts, capitals, revenues and expenses

$>$ Provides a clear image of the assets and debts of public institutions

$>$ Permits the costs measurement and a better analysis of the activities and programs cost

$>$ Puts the accent on transparency and accuracy

$>$ Offers information regarding the performance or the non-performance obtained by public institutions in economic terms and not only of the cash availabilities. Starting from these benefits, Romania also assumed the responsibility of applying the commitment accounting. This fact was gradually realized, starting with 2002, through the adoption of some important regulations, such as:

$>$ The methodological norms on commitment, co-ordination and payment of budgetary expenses (2002)

$>$ The methodological norms on the organization and management of budgetary revenues accounting (2002)

$>$ The methodological norms regarding the re-evaluation and depreciation of fix assets found in the public institution patrimony (2003)

$>$ The methodological norms regarding the organization and management of the public institutions accounting. The accounting plan for public institutions and application instructions of it (2005)

$>$ A new budgetary classification harmonized with the European System of Accounts - SEC 95 and the Governmental Financial Statistics GFS 2001 (2005)

$>$ The methodological norms for the approval of new models of financial situations (2006).

The IPSAS adaptation on global level will improve both the quality and the complexity of the financial information provided by the entities that belong to the worldwide public sector. IPSASB recognize the governments and the national specialists' rights to establish the accounting standards and the directions for financial reporting in their jurisdictions.

IPSASB encourage the IPSAS adoption and the harmonization of the national requirements with IPSAS. The financial situations will be describe as being done accordingly to IPSAS only if they are conform with all the requirements of applicable IPSAS.

IPSASB fulfils its objectives through:

$>$ The issuing of international public sector accounting standards

\footnotetext{
${ }^{1}$ www.ipsas.org
} 


\author{
(online) $=$ ISSN $2285-3642$ \\ ISSN-L = $2285-3642$ \\ Journal of Economic Development, Environment and People \\ Volume 3, Issue 1, 2014 \\ URL: $\underline{\text { http://jedep.spiruharet.ro }}$ \\ e-mail: office jedep@spiruharet.ro
}

$>$ The promoting of standards and international convergence to this standards

$>$ The publication of other documents that offers directions regarding the problems and experiences in the financial reporting in the public sector.

IPSASB issues also other publications without authority, including case studies and occasional papers that concern the problems of financial reporting in the public sector.

These standards are applied through:

$>\quad$ the issuing of IPSAS standards that applies to commitment accounting and IPSAS that applies to cash accounting

$>$ IPSAS establishes the recognition, evaluation and description requirements and information regarding the transactions and events in the general financial statements.

IPSAS are configured so they can be applied to general financial situations of all entities in the public sector. $^{2}$

The entities from public sector include the national governments, regional governments (a state, a province), the local authorities (a town, a locality) and their component entities (departments, agencies, councils, committees) if there are not other observations made.

These standards are not applicable to the business government enterprises, because these apply the International Financial Reporting Standards (IFRS) which are issued by the International Accounting Standard Board (ISAB).

During this process, IPSASB tries every time is possible to maintain the original text and accounting treatment of IFRS, with the exception of the cases where an important problem of the public sector justifies an exception from those and treats the problems of financial reporting of public sector which are not accordingly treated from certain points of view by the existing IFRS, or if the IFRS have not been issued for those specific cases.

In accounting, the asset represents a resource, with a positive economic value, resulted from past events and which will generate economic benefits in future.

The asset defines the way the capital is allocated and used, it underlines how the revaluation of the economic resources takes place and their level of liquidity, and is perceived usually as economic assets. ${ }^{3}$

The fix assets are goods and values that have a long value of use and which are not consumed from the first use, but in time, as a result of a repetitive utilization.

Starting with 2006, all the public institution are oblige to keep the accounting according to the organization norms established according to the International Public Sector Accounting Standards (IPSAS) ${ }^{4}$,

\footnotetext{
${ }^{2}$ www.ipsas.org

${ }^{3}$ Ionescu Cecilia, Bases of Accounting and Proceedings, Fundatia Romania de Maine Publishing House, Bucharest, 2007

${ }^{4}$ www.ipsas.org 


\author{
(online) $=$ ISSN $2285-3642$ \\ ISSN-L = 2285 - 3642 \\ Journal of Economic Development, Environment and People \\ Volume 3, Issue1, 2014 \\ URL: http://jedep.spiruharet.ro \\ e-mail: office jedep@spiruharet.ro
}

issued by the International Public Sector Accounting Standard Board (IPSASB). This institution elaborated a series of standards as it following, which came into force starting with 1st of January 2005:

\begin{tabular}{|l|l|}
\hline IPSAS 1 & The financial situations presentation \\
\hline IPSAS 2 & The cash flow situations \\
\hline IPSAS 3 & $\begin{array}{l}\text { The net surplus or deficit of the period, fundament errors and changes of the } \\
\text { accounting politics }\end{array}$ \\
\hline IPSAS 4 & The effects of the exchange rates fluctuation \\
\hline IPSAS 5 & The costs of debts \\
\hline IPSAS 6 & Consolidated financial situations and the controlled entities accounting \\
\hline IPSAS 7 & The investments in associated entities accounting \\
\hline IPSAS 8 & The financial reporting of the interests in shared association \\
\hline IPSAS 9 & Revenues from exchange transactions \\
\hline IPSAS 10 & The financial reporting in hipper inflation economies \\
\hline IPSAS 11 & Construction contracts \\
\hline IPSAS 12 & Stocks \\
\hline IPSAS 13 & Leasing contracts \\
\hline IPSAS 14 & Events subsequent to date of reporting \\
\hline IPSAS 15 & Financial instruments: information to provide and present \\
\hline IPSAS 16 & Investments in immobile \\
\hline IPSAS 17 & Tangible assets \\
\hline IPSAS 18 & Segments reporting \\
\hline IPSAS 19 & Provisions, contingent debts and assets \\
\hline IPSAS 20 & Information to provide regarding the bound parts \\
\hline IPSAS 21 & The assets depreciation, other than the cash flows \\
\hline
\end{tabular}

The fix assets owned by the public sector are part of the financial situations presentation according to IPSAS 1, and are formed of:

$>$ The intangible fix assets

$>$ The intangible fix assets in progress

$>\quad$ The tangible fix assets

$>$ The tangible fix assets in progress

$>$ The financial fix assets

\title{
3. Conclusions
}

In order to realize the analysis and the patrimony administration, the data and information must be organized in an information system. The events and facts that generate the data are identified, the objectives of the management are established, the owners of information and the way the data are registered and collected are underlined, the methods and instruments for these data processing are chosen, the information destination is defined and the transmission to beneficiary is organized. 


\author{
(online) = ISSN $2285-3642$ \\ ISSN-L = $2285-3642$ \\ Journal of Economic Development, Environment and People \\ Volume 3, Issue 1, 2014 \\ URL: http://jedep.spiruharet.ro \\ e-mail: office jedep@spiruharet.ro
}

\title{
4. References
}

[1] Baluta Aurelian, Solutions Applicable to the Managerial Accountancy in the Enterprises within the Metallurgical Industry under the Conditions of the Aggravating Market Competition, Metalurgia International, Editura Ştiinţifică a F.M.R., nr. 14/2009, ISSN 1582-2214;

[2] Bogdan Anca Mădălina, Modernizarea contabilităţii instituţiilor publice, The IInd International Conference: “One Step to Integration: Opportunities and Threats", 2-3 iunie 2006, Drobeta Turnu-Severin

[3] Chivu Marin, Chivu Maria Ramona, Elena Adelina Stoienescu, Economic Growth Sustaining under Environmental Sustainability and Human Development. A Global Challenge, ISSN (2247-7756), 2012, EconLit, SOCIONET, BIELEFELD, MPRA, INDEX COPERNICUS INTERNATIONAL, EBSCO Publishing, RePEC, DOAJ, Urlich's Web and others Journal of Knowledge Management, Economics and Information Technology, Volume II, Issue 5, October 2012;

[4] Ilincuta Lucian, Resumptions and developments regarding the management of the depreciation methods, Revista Metalurgia International, nr. 3, 2013, ISSN 1582-2214, p. 202 - 213, revistă indexată BDI: Thomson-ISI, Scopus, Ebsco, Proquest;

[5] Ionescu Cecilia, Bases of Accounting and Proceedings, Fundatia Romania de Maine Publishing House, Bucharest, 2007;

[6] Ionescu L, The Corporate Governance Causes of the International Financial Crises, Geopolitics, History, and International Relations, 2(1) 2010, ISSN 1948-9145, pp. 164;

[7] Istrate Olimpius (2011) Current Issues of Digital Education. In: Vlada, Marin (ed.) ICVL. Proceedings of the 6th International Conference on Virtual Learning. Bucharest: University of Bucharest Publishing House;

[8] Istrate Olimpius (2011) Education Staff Working in Elearning Environments: Skills and Competences. In: Roceanu, I. (Ed.) The 7th International Scientific Conference eLearning and Software for Education. Bucharest: Editura Universitara;

*** The International Public Sector Accounting Standards, CECCAR Publishing House, Bucharest, 2013;

*** The Accounting law no. 82/1991 (republished in Official Monitor of Romania, Part 1, no. 48/2005) with ulterior changes and completions;

*** The Public Finances Law no. 500/2002, (M.O.F of Romania, Part, no. 597/2002), with ulterior changes and completions;

*** The Law no. 571/2003 regarding the Fiscal Code (M.O.F of Romania, Part 1, no. 927/2003), with ulterior changes and completions;

*** O.M.F.P. no. $2861 / 2009$ for the approval of the Norms regarding the organization and the performing of assets, debts and capital inventory (M.O.F of Romania, Part 1, no. 704/2009);

*** O.M.F.P no. 3512/2008 regarding the financial documents (M.O.F. of Romania, Part 1, no. 870/2008) with ulterior changes and completions;

*** O.M.F.P no. $1917 / 2005$ for the approval of the Methodological Norms regarding the organization and the accounting of public institutions. The plan of accounts for public institutions and the instructions necessary to its application (M.O.F of Romania, Part 1, no. 1186/2005), with ulterior changes and completions;

*** O.M.F.P no. 1792/2002 for approval of Methodological Norms regarding the commitment, liquidity, repartition and payment of public institutions expenses, and also the organization, evidence and reporting of the budgetary and local commitments (M.O.F of Romania, Part 1, no. 37/2002) with ulterior changes and completions. 